\title{
ANCAMAN, FAKTOR PROTEKTIF, AKTIVITAS, DAN RESILIENSI REMAJA: ANALISIS BERDASARKAN TIPOLOGI SOSIODEMOGRAFI
}

\author{
Raysha Helau Wardhani ${ }^{\left.{ }^{*}\right)}$, Euis Sunarti², Istiqlaliyah Muflikhati ${ }^{2}$ \\ ${ }_{1}$ Program Studi IImu Keluarga dan Perkembangan Anak, Sekolah Pascasarjana, Institut Pertanian Bogor, \\ Bogor 16680, Indonesia \\ 2 Departemen IImu Keluarga dan Konsumen, Fakultas Ekologi Manusia, Institut Pertanian Bogor, \\ Bogor 16680, Indonesia \\ *) Email: rayshahelau@yahoo.com
}

\begin{abstract}
Abstrak
Penelitian ini bertujuan untuk menganalisis perbedaan ancaman, faktor protektif, aktivitas, dan resiliensi pada remaja berdasarkan jenis kelamin, tipologi wilayah, dan status pekerjaan ibu; dan menganalisis pengaruh karakterisitik remaja, karakteristik keluarga, ancaman, faktor protektif, dan aktivitas terhadap resiliensi remaja. Lokasi penelitian bertempat di salah satu SMP yang berada di wilayah perkotaan dan perdesaan di Bogor yang dipilih secara sengaja. Pemilihan contoh dilakukan secara sengaja (purposive sampling) dengan jumlah 133 siswa yang terdiri dari 84 remaja perempuan dan 49 remaja laki-laki. Ancaman pada remaja laki-laki dan remaja di kota lebih tinggi dibandingkan dengan ancaman pada remaja perempuan dan remaja di desa. Sebaliknya, faktor protektif (internal dan eksternal) dan resiliensi pada remaja perempuan lebih tinggi dibandingkan dengan remaja laki-laki. Faktor protektif eksternal, aktivitas di luar rumah, dan resiliensi pada remaja di wilayah perdesaan lebih tinggi dibandingkan dengan remaja di perkotaan. Faktor protektif total, faktor protektif internal, faktor protektif eksternal (sekolah dan teman sebaya), dan resiliensi remaja dengan ibu bekerja lebih tinggi dibandingkan remaja dengan ibu tidak bekerja. Resiliensi remaja dipengaruhi oleh faktor protektif (internal dan eksternal) dan aktivitas remaja. Resiliensi remaja meningkat dengan bertambahnya faktor protektif dan aktivitas remaja.
\end{abstract}

Kata kunci: aktivitas, ancaman, faktor protektif, remaja, resiliensi

\section{Hazard, Protective Factors, Activities, and Resiliency of Adolescent: Analysis Based on Sociodemographic Typology}

\begin{abstract}
The aims of this study were to analyze the differences of hazard, protective factors, activities, and resilience among adolescents by gender, district, and mother's employment status; and to analyze the influence of adolescence characteristics, family characteristics, hazard, protective factors, and activities on adolescent's resiliency. Location of this research were two junior high schools that were represented the urban and rural area in Bogor and selected purposively. Participants of this research were 133 students consisting of 84 girls and 49 boys. The result showed that hazard of boys and adolescents that were from urban area were higher than girls and adolescents that were from rural area. However, protective factors (internal and external) and resilience of girls was higher than boys. External protective factors, outside activities, and resilience of adolescents in a rural area were higher than in urban area. Total protective factors, internal protective factors, external protective factors (school and peers), and resilience of adolescents whom mother was working was higher than adolescents whom mother was not working. The resilience of adolescent was affected by protective factors (internal and external) and adolescent's activities. Resilience of adolescents is increasing while protective factors and adolescents' activities were increasing.
\end{abstract}

Keywords: activities, adolescent, hazard, protective factors, resilience

\section{PENDAHULUAN}

Peningkatan perilaku remaja saat ini menjadi isu penting di Indonesia. Usia remaja merupakan periode yang mana anak sedang mencari dan membangun identitas diri (Santrock, 2011), dan anak pada usia ini sangat rentan terhadap berbagai tekanan dan pengaruh negatif dari teman sebayanya. Masa remaja merupakan masa yang menyenangkan dalam rentang manusia (Steinberg, 1993) karena seorang individu mulai membuat keputusan untuk dirinya sendiri. Anak remaja saat ini menghadapi dinamika kehidupan akibat 
perubahan sosial ekonomi, perkembangan informasi dan teknologi, dan juga globalisasi. Menurut Sunarti, Rochimah, dan Islamia (2015), perubahan pada anak remaja di satu sisi menyediakan kesempatan dan peluang untuk dapat maju dan berkembang namun sekaligus bisa menjadi sumber masalah, kerentanan, bahkan ancaman bagi remaja yang masih dalam proses perkembangan dan membangun jati diri (self identity and integrity). Risiko perkembangan anak pada usia remaja terkait dengan dinamika dan perubahan dalam kehidupan sehingga menuntut ketangguhan agar anak remaja terhindar dari penyimpangan perkembangan (Sunarti Rochimah, \& Islamia, 2015). Dengan demikian, remaja masa kini semakin dituntut memiliki ketangguhan atau kelentingan (resiliensi) agar tidak mengalami kondisi yang akan mengganggu tugas perkembangannya.

Ditengah upaya pembangunan kualitas remaja agar menjadi generasi penerus bangsa yang berkualitas, saat ini telah diketahui terdapat berbagai masalah yang dihadapi anak Indonesia, diantaranya adalah Perilaku Sosial Menyimpang (PSM). Data dari Komisi Perlindungan Anak Indonesia menyebutkan bahwa dalam kurun waktu tiga tahun sebanyak 301 peristiwa tawuran pelajar terjadi di wilayah Jabodetabek dan dari data tersebut 46 orang pelajar tewas (Laras, 2015). Pada tahun 2010 tercatat ada 102 kejadian tawuran dengan korban meninggal sebanyak 17 orang. Sementara itu, pada tahun 2011 jumlah kasus menurun yakni hanya ada 96 kasus dengan korban meninggal sebanyak 12 orang. Pada tahun 2012, jumlah kasus tawuran meningkat menjadi 103 kasus tawuran dengan jumlah korban tewas sebanyak 17 orang. Data juga menyebutkan bahwa terdapat 229 kasus tawuran pelajar sejak bulan Januari sampai dengan bulan Oktober tahun 2013. Jumlah ini meningkat sekitar 44 persen dibandingkan dengan data tahun sebelumnya yang hanya 128 kasus. Dalam 229 kasus kekerasan antarpelajar Sekolah Menengah Pertama (SMP) dan Sekolah Menengah Atas (SMA) terdapat 19 orang siswa yang meninggal dunia. Data ini juga didukung oleh data dari hasil penelitian Sunarti Rochimah, dan Islamia (2015) yang menemukan bahwa remaja di Kota dan Kabupaten Bogor memiliki kecenderungan yang tinggi untuk terlibat dalam merokok, tawuran, seks bebas, dan narkoba. Lebih lanjut, penelitian juga menemukan bahwa remaja lakilaki lebih sering terlibat kenakalan secara umum, merokok, dan mudah diajak tawuran.
Remaja lebih banyak melakukan aktivitas di luar rumah bersama dengan teman-teman sebaya yang mencoba malakukan aktivitas negatif seperti merokok, minum alkohol, dan mengonsumsi obat-obat terlarang. Remaja cenderung mengikuti teman sebayanya tanpa memedulikan akibat dari perbuatannya. Remaja merupakan calon penerus bangsa sehingga perlu dilindungi dari berbagai masalah. Salah satu bentuk perlindungan khusus kepada remaja adalah melalui pencegahan, yaitu membangun ketangguhan (resiliensi) remaja sehingga remaja memiliki kemampuan dalam mencegah, mengantisipasi, beradaptasi, dan menghadapi masalah.

Menurut Ungar (2008), resiliensi merupakan kemampuan yang membuat seseorang mampu bertahan dan bahkan dapat tetap bergerak maju dalam kondisi sulit sekalipun. Resiliensi juga dapat didefinisikan sebagai keberhasilan untuk dapat mengatasi perubahan atau ketidakberuntungan atau dengan kata lain resiliensi adalah kemampuan untuk bangkit dan melanjutkan kehidupan setelah jatuh (Wagnild \& Young, 1993). Ada dua faktor yang memengaruhi resiliensi individu, yaitu ancaman dan faktor protektif.

Ancaman adalah kejadian hidup atau pengalaman yang berhubungan dengan peningkatan permasalahan pada perilaku. Ancaman dapat berasal dari diri individu remaja itu sendiri, keluarga, maupun masyarakat yang merupakan suatu prediktor awal dari sebuah hasil yang tidak menguntungkan, dan sesuatu yang membuat orang menjadi rentan atau variabel yang mengarahkan pada ketidakmampuan, atau mediator yang menyebabkan terjadinya suatu perilaku yang bermasalah (Kaplan, 1999). Ancaman merupakan mediator awal yang dapat menyebabkan terjadinya perilaku yang bermasalah atau maladaptif.

Beberapa studi terdahulu menemukan bahwa faktor-faktor ancaman yang dapat memengaruhi secara negatif perkembangan anak-anak yang terlahir sehat antara lain kemiskinan; pengalaman hidup yang negatif seperti penganiayaan, kekerasan, pelecehan, dan kurangnya perhatian dari orangtua; dan status minoritas (Masten, 2001; Rak \& Patterson, 1996 dalam Zolkoski \& Bullock, 2012). Akumulasi dari risiko-risiko tersebut selama hidup anak-anak dan remaja mengakibatkan hasil yang buruk atau negatif yang dapat berbentuk penggunaan obat-obat terlarang, perilaku kekerasan, prestasi akademik yang buruk, putus sekolah, 
kehamilan remaja, tindak pindana remaja, gangguan psikologis dan gangguan emosi (Fergus \& Zimmerman, 2005; Resnick et al., 2000; Masten, 2001 dalam Zolkoski \& Bullock, 2012).

Berbeda dengan ancaman, faktor protektif merupakan faktor yang dapat membantu dalam melindungi remaja dari ancaman (Masten \& Coatsworth, 1998). Faktor protektif cenderung mengurangi kesempatan remaja untuk melakukan hal-hal yang negatif dan faktor tersebut dapat meningkatkan perilaku positif remaja. Faktor protektif dibagi menjadi dua, yaitu faktor protektif internal dan eksternal. Faktor protektif internal dapat berasal dari individu remaja itu sendiri. Sementara itu, faktor protektif eksternal adalah faktor yang berasal dari luar individu tersebut dan tercermin dalam wujud dan kualitas dari hubungan di dalam maupun di luar keluarga (Mandleco \& Peery, 2000). Faktor protektif eksternal terdiri dari keluarga, sekolah, teman sebaya, dan masyarakat serta dapat juga berupa keterlibatan remaja dalam aktivitas baik di dalam maupun di luar rumah. Menurut Benzies \& Mychasiuk (2009), resiliensi akan menjadi optimal ketika faktor protektif diperkuat di semua tingkat interaktif model sosio-ekologis (individu, keluarga, dan masyarakat).

Ancaman dan faktor protektif ditentukan oleh aktivitas remaja. Aktivitas remaja merupakan kecenderungan remaja untuk membentuk kelompok melakukan berbagai aktivitas bersama dengan teman-teman sebayanya. Aktivitas remaja pada penelitian ini ialah aktivitas yang dilakukan di dalam rumah dan di luar rumah. Aktivitas ini membuka peluang bagi remaja untuk terpapar berbagai macam jenis ancaman yang berasal dari lingkungan sosialnya. Namun, di sisi lain berbagai aktivitas yang dilakukan remaja juga dapat mendukung terbentuknya faktor protektif internal maupun eksternal remaja. Melalui berbagai aktivitas yang dilakukan baik di dalam maupun di luar rumah, remaja dapat mengembangkan kompetensi diri, terbiasa berinteraksi, membangun komunikasi yang baik, dan bekerjasama dengan orang lain.

Upaya peningkatan resiliensi remaja dapat didukung dengan melakukan kajian mengenai faktor yang memengaruhi resiliensi remaja. Penelitian tentang resiliensi di Indonesia masih relatif baru. Berdasarkan beberapa penelitian terdahulu, resiliensi dapat diukur pada individu dalam kesulitan, misalnya korban bencana alam (Volia, 2007), penggunaan narkoba (Fergus \& Zimmerman, 2005), anak yang memiliki keter-batasan fisik atau penyakit berat (Alriksson-Schmidt, Wallander, \& Biasini, 2007), anak yang pernah mengalami abuse atau neglect di masa kecil (Yuliatin, 2007), dan resiliensi berdasarkan tipologi wilayah (Martiastuti, 2011). Selain itu, penelitian resiliensi juga dapat dilakukan pada kelompok individu yang berada dalam kondisi normatif. Dalam hal ini, resiliensi dilihat sebagai sebuah investasi yang dimiliki individu yang diharapkan akan muncul pada saat individu tersebut mengalami kesulitan.

Penelitian ini bertujuan untuk menganalisis perbedaan ancaman, faktor protektif, aktivitas, dan resiliensi pada remaja berdasarkan jenis kelamin, tipologi wilayah, dan status pekerjaan ibu. Selain itu, penelitian ini juga bertujuan untuk menganalisis pengaruh karakterisitik remaja, karakteristik keluarga, ancaman, faktor protektif, dan aktivitas terhadap resiliensi remaja baik di wilayah perdesaan maupun perkotaan.

\section{METODE}

Penelitian ini menggunakan desain cross sectional. Penelitian dilakukan di Sekolah Menengah Pertama (SMP) di Kota Bogor sebagai representasi wilayah kota dan Kabupaten Bogor sebagai representasi wilayah desa. Lokasi penelitian dipilih secara purposive. Kerangka contoh dalam penelitian ini adalah peserta didik kelas IX yang diidentifikasi berdasarkan tipologi wilayah (kota dan desa), status pekerjaan ibu (ibu bekerja dan ibu tidak bekerja), dan jenis kelamin (laki-laki dan perempuan). Contoh dipilih secara purposive berdasarkan kesediaannya untuk menjadi responden sehingga didapatkan 150 siswa kelas IX, akan tetapi hanya 133 siswa yang mengisi data secara lengkap yang terdiri atas 84 siswa perempuan dan 49 siswa laki-laki.

Penelitian ini menggunakan data primer yang dikumpulkan dengan menggunakan metode self-administered, yaitu dengan memberikan kuesioner terstruktur kepada responden dan meminta responden untuk mengisinya sendiri setelah mendapatkan penjelasan dan panduan dari peneliti. Data primer yang diambil dalam penelitian ini meliputi karakteristik remaja (usia, jenis kelamin, urutan kelahiran), karakteristik keluarga (pendidikan orang tua, pekerjaan ibu, dan pendapatan orang tua), ancaman, faktor protektif (internal dan eksternal), dan resiliensi remaja.

Variabel resiliensi remaja dalam penelitian ini diukur dengan menggunakan instrumen dari 
Wagnild dan Young (1993). Variabel resiliensi terdiri atas dimensi kompetensi personal (17 pertanyaan) dan dimensi penerimaan diri dan kehidupan (6 pertanyaan). Pengukuran terhadap resiliensi remaja menggunakan skala Likert, meliputi SS=Sangat Setuju; S=Setuju; KS=Kurang Setuju; TS=Tidak Setuju. Instrumen ini memiliki nilai reabilitas yang baik dengan nilai Cronbach's alpha sebesar 0,900.

Variabel ancaman sebagai salah satu variable bebas diukur dengan menggunakan instrumen yang dikembangkan oleh Martiastuti (2011). Variabel ancaman terdiri atas ancaman yang berasal dari lingkungan (6 pertanyaan), ancaman yang berasal dari rumah (5 pertanyaan), dan ancaman yang berasal dari individu (4 pertanyaan). Pertanyaan tentang faktor protektif eksternal keluarga dinilai dengan menggunakan skala Likert yang terdiri dari TP=Tidak Pernah; HTP=Hampir Tidak Pernah; $\mathrm{S}=$ Sering; $\mathrm{SS}=$ Sangat Sering. Instrumen ini memiliki nilai reliabilitas yang baik dengan nilai cronbach's alpha sebesar 0,811.

Variabel faktor protektif internal dan eksternal diukur dengan menggunakan instrumen dari Resilience Youth Development (Furlong, Ritchey, \& O'Brennan, 2009). Faktor protektif internal yang terdiri dari dimensi kerjasama dan komunikasi, self-efficacy, pemecahan permasalahan, empati, self-awareness, tujuan, dan aspirasi masing-masing terdiri atas tiga pertanyaan. Pengukuran faktor protektif internal dijawab dengan menggunakan skala Likert, meliputi $S S=S a n g a t \quad$ Setuju; $S=S e t u j u$; KS=Kurang Setuju; TS=Tidak Setuju. Instrumen ini memiliki nilai reliabilitas yang baik dengan nilai Cronbach's alpha sebesar 0,940.

Sementara itu, variabel faktor protektif eksternal yang meliputi sekolah dan masyarakat, masingmasing terdiri atas sembilan pertanyaan sedangkan faktor protektif teman sebaya terdiri atas enam pertanyaan. Selanjutnya, untuk variabel faktor protektif eksternal keluarga diukur dengan menggunakan instrumen dari Moos \& Moos (2009), yang terdiri atas hubungan (13 pertanyaan), perkembangan personal (12 pertanyaan), dan sistem pemeliharaan (6 pertanyaan). Variabel faktor protektif eksternal keluarga ini diukur dengan menggunakan skala Likert, meliputi TP=Tidak Pernah; HTP=Hampir Tidak Pernah; $\mathrm{S}=$ Sering; SS=Sangat Sering. Instrument ini memiliki nilai reabilitas yang baik dengan nilai Cronbach's alpha sebesar 0,650.

Selanjutnya, variabel aktivitas remaja diukur dengan menggunakan insrumen yang dikembangkan Ruhidawati (2005). Variabel aktivitas terdiri atas aktivitas di dalam rumah yang terdiri atas tujuh pertanyaan dan aktivitas di luar rumah terdiri atas sembilan pertanyaan. Pertanyaan tentang aktivitas dinilai dengan menggunakan skala Likert meliputi TP=Tidak Pernah; HTP=Hampir Tidak Pernah; $\mathrm{S}=$ Sering; $\mathrm{SS}=$ Sangat Sering .

Data yang telah dikumpulkan selanjutnya dihitung indeksnya dan dikategorikan menjadi tiga kategori, yaitu rendah $(0,0-60,0)$, sedang $(60,0-80,0)$, dan tinggi $(80,0-100,0)$. Analisis data yang digunakan untuk menjawab masingmasing tujuan adalah analisis deskriptif, uji beda $t$, dan uji regresi linear berganda. Analisis deskriptif digunakan untuk menghitung frekuensi, nilai minimum, nilai maksimum, nilai rata-rata, dan standar deviasi. Uji beda t untuk menganalisis perbedaan variabel penelitian berdasarkan jenis kelamin, tipologi wilayah, dan status pekerjaan ibu. Uji regresi linear berganda digunakan untuk menganalisis pengaruh karakterisitik remaja dan keluarga, ancaman, faktor protektif, dan aktivitas terhadap resiliensi remaja.

\section{HASIL}

\section{Karakterisitik Remaja dan Keluarga}

Remaja dalam penelitian ini terdiri atas remaja laki-laki dan perempuan. Hasil penelitian menunjukkan bahwa lebih dari dua pertiga remaja $(63,2 \%)$ berjenis kelamin perempuan. Hasil penelitian menyebutkan bahwa lebih dari empat per lima remaja $(85,0 \%)$ berusia 14 tahun. Rata-rata usia remaja yang terlibat dalam penelitian ini adalah 13,95 tahun (Tabel 1). Berdasarkan urutan kelahiran, remaja dikelompokkan menjadi tiga kategori yaitu anak sulung (pertama), anak tengah (anak diantara anak pertama dan terakhir), dan anak bungsu (anak terakhir). Hasil penelitian menunjukkan bahwa hampir separuh remaja $(49,6 \%)$ dalam penelitian ini merupakan anak sulung atau anak pertama dan lebih dari seperempat $(27,8 \%)$ merupakan anak bungsu. Sementara itu, dilihat berdasarkan besar keluarga, rata-rata remaja dalam penelitian ini tinggal dalam keluarga berukuran sedang dengan rata-rata besar keluarga adalah 4,95 orang.

Rata-rata lama pendidikan ayah remaja laki-laki adalah 15,7 tahun dan ayah dari remaja perempuan adalah 15,0 tahun. Rata-rata lama pendidikan ayah dari remaja yang tinggal di kota lebih tinggi (16,5 tahun) dibandingkan dengan pendidikan ayah dari remaja yang tinggal di desa (14,1 tahun). 
Tabel 1 Nilai minimum, nilai maksimum, nilai rata-rata, dan standar deviasi dari karakteristik remaja dan karakteristik keluarga

\begin{tabular}{lrrr}
\hline Karakteristik & Minimum & Maksimum & \multicolumn{1}{c}{ Rata-rata \pm SD } \\
\hline Usia remaja (tahun) & 13 & 15 & $13,95 \pm 0,387$ \\
Lama pendidikan ayah (tahun) & 12 & 21 & $15,25 \pm 2,527$ \\
Lama pendidikan ibu (tahun) & 4 & 21 & $14,46 \pm 2,864$ \\
Jumlah anggota keluarga (orang) & 2 & 7 & $4,53 \pm 0,93$ \\
Pendapatan keluarga (Rp/bulan) & 1.500 .000 & 23.000 .000 & $6.872 .932 \pm 4.938 .026$ \\
Pendapatan per kapita (Rp/bulan) & 285.714 & 6.666 .676 & $1.574 .814 \pm 1.172 .560$ \\
\hline
\end{tabular}

Rata-rata lama pendidikan ibu dari remaja perempuan dan laki-laki berada pada kisaran 14,3 tahun. Rata-rata lama pendidikan ibu dari remaja yang tinggal di kota lebih lama $(15,4$ tahun) dibandingkan dengan pendidikan ibu dari remaja yang tinggal di desa (13,4 tahun). Pada penelitian ini masih ditemukan ibu dari remaja yang tidak menamatkan pendidikan dasar yaitu hanya bersekolah selama 4 tahun. Meskipun demikian, data yang tersaji pada Tabel 1 menunjukkan bahwa rata-rata lama pendidikan ayah dan ibu keseluruhan remaja dalam penelitian ini telah lulus SMA.

Selanjutnya, rata-rata pendapatan keluarga remaja laki-laki lebih besar (Rp1.607.000,00/kapita/bulan) dibandingkan dengan rata-rata pendapatan keluarga remaja perempuan (Rp1.556.000,00/kapita/bulan). Sementara itu, rata-rata pendapatan keluarga remaja yang tinggal di kota lebih besar (Rp1.992.000,00/kapita/bulan) dibandingkan dengan remaja yang tinggal di desa (Rp1.210.000,00/kapita/bulan). Secara keseluruhan, rata-rata pendapatan keluarga per kapita per bulan adalah Rp1.574.814,00.

\section{Ancaman}

Ancaman merupakan salah satu prediktor awal dari sebuah hasil yang tidak menguntungkan dan sesuatu yang membuat orang menjadi rentan; atau dapat juga dipahami sebagai mediator yang menyebabkan terjadinya perilaku bermasalah. Hasil penelitian menunjukkan bahwa hampir seluruh remaja laki-laki dan perempuan (>95,0\%) memiliki ancaman yang tergolong rendah. Selanjutnya, hasil analisis uji beda $t$ menunjukkan bahwa ancaman berbeda signifikan berdasarkan jenis kelamin (Tabel 2). Ancaman yang diterima remaja laki-laki $(14,19 \%)$ lebih tinggi dibandingkan dengan yang diterima remaja perempuan (10,74\%). Ancaman juga berbeda signifikan berdasarkan tipologi wilayah. Ancaman yang diterima remaja yang tinggal di kota $(13,79 \%)$ lebih tinggi dibandingkan dengan remaja yang tinggal di desa $(10,45 \%)$.

Tabel 2 Hasil analisis uji beda variabel ancaman, faktor protektif dan resiliensi berdasarkan jenis kelamin, tipologi wilayah, dan status pekerjaan ibu

\begin{tabular}{|c|c|c|c|c|c|c|c|c|c|}
\hline \multirow[t]{2}{*}{ Variabel } & \multicolumn{2}{|c|}{$\begin{array}{c}\text { Jenis } \\
\text { Kelamin }\end{array}$} & \multirow[t]{2}{*}{$p$-value } & \multicolumn{2}{|c|}{ Wilayah } & \multicolumn{4}{|c|}{ Status } \\
\hline & $\mathrm{L}$ & $P$ & & Kota & Desa & & $\mathrm{B}$ & TB & \\
\hline Ancaman & 14,19 & 10,74 & $0,041^{*}$ & 13,79 & 10,45 & $0,040^{*}$ & 12,04 & 11,98 & 0,972 \\
\hline Faktor protektif & 64,76 & 71,00 & $0,001^{* *}$ & 67,54 & 69,72 & 0,250 & 71,18 & 66,84 & $0,022^{*}$ \\
\hline Faktor protektif internal & 71,84 & 80,91 & $0,006^{*}$ & 78,16 & 77,05 & 0,869 & 80,86 & 75,09 & $0,043^{*}$ \\
\hline $\begin{array}{ll}\text { - } & \text { Kerjasama dan } \\
\text { komunikasi }\end{array}$ & 67,12 & 75,93 & $0,000^{\star *}$ & 73,66 & 71,83 & 0,577 & 76,41 & 69,88 & $0,005^{*}$ \\
\hline - Self-efficacy & 65,98 & 71,69 & $0,006^{*}$ & 70,07 & 69,18 & 0,758 & 72,51 & 67,39 & $0,009^{*}$ \\
\hline - Empati & 72,79 & 82,67 & $0,000^{* *}$ & 80,47 & 77,77 & 0,427 & 82,46 & 76,47 & $0,008^{*}$ \\
\hline - Pemecahanan masalah & 63,95 & 78,43 & $0,000^{* *}$ & 71,86 & 74,18 & 0,566 & 75,24 & 71,49 & 0,035 \\
\hline - Self-awareness & 78,68 & 85,95 & $0,008^{*}$ & 84,05 & 82,63 & 0,688 & 86,74 & 80,70 & $0,009^{*}$ \\
\hline - Tujuan dan aspirasi & 82,54 & 90,74 & $0,009^{*}$ & 88,88 & 86,69 & 0,583 & 91,81 & 84,64 & $0,006^{*}$ \\
\hline Faktor protektif eksternal & 60,66 & 65,45 & $0,004^{*}$ & 61,72 & 65,40 & $0,021^{*}$ & 65,48 & 62,34 & 0,053 \\
\hline - Keluarga & 55,39 & 60,05 & $0,003^{*}$ & 55,58 & 60,75 & $0,001^{\star *}$ & 58,28 & 58,39 & 0,941 \\
\hline - Sekolah & 68,32 & 71,83 & 0,234 & 68,82 & 72,03 & 0,256 & 74,68 & 67,42 & $0,011^{*}$ \\
\hline - Masyarakat & 64,72 & 68,54 & 0,278 & 67,35 & 66,93 & 0,901 & 69,92 & 65,04 & 0,153 \\
\hline - Teman Sebaya & 70,41 & 79,97 & $0,011^{*}$ & 74,73 & 77,93 & 0,383 & 83,04 & 71,49 & $0,001^{* *}$ \\
\hline Aktivitas & 49,85 & 51,30 & 0,563 & 49,31 & 52,04 & 0,258 & 64,03 & 61,33 & 0,131 \\
\hline - Luar rumah & 52,38 & 42,32 & $0,001^{\star *}$ & 47,51 & 48,01 & 0,879 & 65,11 & 61,91 & 0,165 \\
\hline - Dalam rumah & 51,71 & 56,29 & 0,132 & 55,10 & 51,71 & 0,281 & 62,96 & 60,75 & 0,364 \\
\hline Resiliensi & 62,12 & 68,63 & $0,011^{*}$ & 64,88 & 67,42 & 0,272 & 68,95 & 64,19 & $0,039^{*}$ \\
\hline
\end{tabular}

Keterangan: *signifikan pada $p \leq 0,05 ;{ }^{* *}$ signifikan pada $p \leq 0,01$; L= Laki-laki; P= Perempuan; B= Bekerja; TB= Tidak Bekerja 


\section{Faktor Protektif}

Faktor protektif adalah segala sesuatu yang berasal dari individu, keluarga, dan masyarakat yang dapat melindungi seseorang dari efekefek negatif ancaman dan membentuk resiliensi. Pada penelitian ini, faktor protektif dikelompokkan menjadi faktor protektif internal dan eksternal. Faktor protektif internal yaitu faktor yang ada dalam diri individu terdiri dari kerjasama dan komunikasi, self-efficacy, empati, pemecahan masalah, self-awareness, serta tujuan dan aspirasi. Selanjutnya faktor eksternal yaitu faktor yang berasal dari luar individu, yaitu keluarga dan lingkungan (sekolah, teman sebaya, dan masyarakat).

Hasil penelitian menemukan bahwa terdapat perbedaan signifikan pada faktor protektif total antara remaja laki-laki dan perempuan. Remaja perempuan ditemukan memiliki faktor protektif total lebih baik dibandingkan dengan remaja laki-laki. Perbedaan signifikan variabel faktor protektif total juga ditunjukkan antara remaja dengan ibu bekerja dan ibu tidak bekerja. Remaja dengan ibu bekerja diketahui memiliki faktor protektif total lebih baik dibandingkan dengan remaja yang ibunya tidak bekerja (Tabel 2).

Hasil analisis lebih lanjut ditemukan bahwa faktor protektif internal total dan seluruh dimensi faktor protektif internal (kerjasama dan komunikasi, self-efficacy, empati, pemecahan masalah, self-awareness, serta tujuan dan aspirasi) berbeda nyata dan signifikan antara remaja laki-laki dan remaja perempuan. Remaja perempuan memiliki faktor protektif internal total yang mencakup kerjasama dan komunikasi, self efficacy, empati, pemecahan masalah, self-awareness, serta tujuan dan aspirasi dengan capaian yang lebih baik dibandingkan dengan remaja laki-laki. Sementara itu, perbedaan signifikan juga ditemukan pada variabel faktor protektif internal total dan dimensi faktor protektif internal (kecuali pemecahan masalah) berdasarkan status ibu bekerja. Faktor protektif internal total dan dimensi kerjasama dan komunikasi, selfefficacy, empati, self-awareness, serta tujuan dan aspirasi pada remaja dengan ibu bekerja lebih baik dibandingkan dengan remaja yang ibunya tidak bekerja (Tabel 2).

Selain itu, temuan penelitian juga menunjukkan adanya perbedaan signifikan pada faktor protektif eksternal total berdasarkan jenis kelamin dan tipologi wilayah. Remaja perempuan dan remaja di desa memiliki faktor protektif eksternal total lebih baik dibandingkan dengan remaja laki-laki dan remaja di kota. Sementara itu, berdasarkan dimensi protektif eksternal keluarga, ditemukan perbedaan signifikan antara remaja laki-laki dengan remaja perempuan serta remaja di kota dengan remaja di desa. Faktor protektif yang berasal dari keluarga pada remaja perempuan lebih baik dibandingkan dengan remaja laki-laki. Selain itu, faktor protektif yang berasal dari keluarga pada remaja di desa lebih baik dibandingkan dengan remaja di kota. Selanjutnya, hasil analisis juga menemukan faktor protektif dari sekolah pada remaja yang ibunya bekerja lebih baik dibandingkan dengan remaja yang ibunya tidak bekerja. Faktor protektif eksternal dari teman sebaya pada remaja perempuan ditemukan lebih baik dibandingkan dengan remaja laki-laki. Selain itu, faktor protektif eksternal dari teman sebaya pada remaja yang ibunya bekerja lebih baik dibandingkan dengan remaja yang ibunya tidak bekerja (Tabel 2).

\section{Aktivitas Remaja}

Aktivitas remaja merupakan kecenderungan remaja untuk membentuk kelompok dan melakukan berbagai aktivitas bersama dengan teman-teman sebayanya. Aktivitas remaja pada penelitian ini ialah aktivitas yang dilakukan di dalam rumah dan di luar rumah. Hasil penelitian menunjukkan tidak adanya perbedaan yang signifikan pada aktivitas remaja berdasarkan jenis kelamin, tipologi wilayah, dan status pekerjaan ibu. Apabila aktivitas remaja dianalisis berdasarkan jenisnya (dalam dan luar rumah) maka diperolah hasil bahwa aktivitas remaja di luar rumah berbeda signifikan berdasarkan jenis kelamin. Rata-rata indeks yang dimiliki remaja laki-laki $(52,38)$ lebih tinggi dibandingkan remaja perempuan $(42,32)$. Hasil ini menunjukkan bahwa aktivitas di luar rumah pada remaja laki-laki lebih sering dibandingkan remaja perempuan (Tabel 2).

\section{Resiliensi Remaja}

Resiliensi remaja pada penelitian ini adalah prediksi terhadap kemampuan yang dimiliki remaja untuk mampu bertahan dalam situasi yang kurang menguntungkan atau penuh tekanan yang diukur dari aspek kompetensi personal dan penerimaan atas diri dan kehidupan. Hasil penelitian (Tabel 2) menemukan bahwa resiliensi berbeda signifikan antara remaja perempuan dan lakilaki. Remaja perempuan (rata-rata $=68,63$ ) diketahui memiliki kemampuan bertahan (resiliensi) lebih baik dibandingkan dengan remaja laki-laki (rata-rata $=62,12$ ). Resiliensi remaja juga berbeda signifikan berdasarkan 
status pekerjaan ibu. Nilai rata-rata resiliensi remaja yang ibunya bekerja $(68,95)$ lebih tinggi dibandingkan dengan nilai rata-rata resiliensi remaja yang ibunya tidak bekerja $(64,19)$.

\section{Pengaruh Karakterisitik Remaja, Karakteristik Keluarga, Ancaman, Faktor Protektif, dan Aktivitas terhadap Resiliensi Remaja}

Hasil analisis model regresi yang dibangun memiliki koefisien determinasi (Adjusted $R$ Square) sebesar 0,583 (Tabel 3). Hasil tersebut mengindikasikan bahwa 58,3 persen varian resiliensi remaja dapat dijelaskan oleh variabel yang ada dalam model (karakteristik remaja, karakteristik keluarga, ancaman, faktor protektif, dan aktivitas remaja) sedangkan sisanya sebesar 41,7 persen dipengaruhi oleh variabel lain yang tidak diteliti.

Berdasarkan hasil analisis regresi yang disajikan pada Tabel 3, diketahui bahwa resiliensi remaja dipengaruhi oleh faktor protektif $(B=0,756, p=0,001)$, faktor protektif internal $(B=0,248, p=0,000)$, faktor protektif eksternal keluarga $(B=0,231, p=0,029)$, faktor protektif eksternal sekolah $(B=0,126, p=0,080)$, faktor protektif eksternal teman sebaya $(B=0,155, \quad p=0,005)$, serta aktivitas remaja $(B=0,187, p=0,068)$. Hasil ini dapat dikan bahwa peningkatan resiliensi remaja dipengaruhi secara nyata oleh bertambahnya faktor protektif, faktor protektif internal, faktor protektif eksternal (keluarga, sekolah, dan teman sebaya), serta aktivitas remaja.

\section{PEMBAHASAN}

Hasil penelitian menunjukkan bahwa resiliensi remaja berbeda signifikan berdasarkan jenis kelamin. Remaja yang berjenis kelamin perempuan memiliki resiliensi yang lebih baik dibandingkan dengan remaja yang berjenis kelamin laki-laki. Hasil ini sejalan dengan hasil penelitian LaFromboise et al. (2006) yang mengemukakan adanya kontribusi dari faktor jenis kelamin terhadap resiliensi seorang individu. Remaja perempuan juga memiliki faktor protektif internal yang lebih baik dibandingkan dengan remaja laki-laki. hasil ini sesusai dengan temuan penelitian Sunarti, Rochimah, dan Islamia (2015) menemukan bahwa remaja perempuan memiliki resiliensi dan faktor protektif internal yang lebih baik dibandingkan dengan remaja laki-laki. Hasil tersebut menunjukkan bahwa perempuan memiliki kemampuan untuk dapat bekerjasama, mampu menjalin komunikasi, memiliki selfefficacy, empati, mampu memecahkan masalah, dan memiliki self-awareness yang lebih baik serta lebih memiliki tujuan dan aspirasi dalam hidup. Selain itu, faktor protektif eksternal yang dimiliki oleh remaja perempuan juga lebih tinggi dibandingkan dengan remaja laki-laki.

Tabel 3 Hasil analisis pengaruh karakterisitik remaja, karakteristik keluarga, ancaman, dan faktor protektif terhadap resiliensi remaja

\begin{tabular}{|c|c|c|c|}
\hline Variabel & $\mathrm{B}$ & $\beta$ & Sig. \\
\hline Konstanta & $-38,82$ & & 2,850 \\
\hline \multicolumn{4}{|l|}{ Karakteristik remaja } \\
\hline - Usia (tahun) & 2,240 & 0,066 & 0,302 \\
\hline - Jenis kelamin remaja ( $0=$ Laki-laki; $1=$ Perempuan) & 0,487 & 0,018 & 0,783 \\
\hline - Wilayah ( $0=$ Desa; $1=$ Kota $)$ & 0,664 & 0,025 & 0,716 \\
\hline \multicolumn{4}{|l|}{ Karakterstik keluarga } \\
\hline - Pendidikan ibu (tahun) & 0,723 & 0,041 & 0,501 \\
\hline - Status Pekerjaan ibu ( $0=$ =tidak bekerja; $1=$ bekerja) & 0,608 & 0,023 & 0,745 \\
\hline - Pendapatan per Kapita (Rp/bulan) & $-0,044$ & $-0,039$ & 0,593 \\
\hline Ancaman (indeks) & $-0,071$ & $-0,050$ & 0,401 \\
\hline Faktor protektif (indeks) & 0.756 & 0.590 & $0,001^{* \star \star}$ \\
\hline Faktor protektif internal (indeks) & 0,248 & 0,305 & $0,000^{\star \star \star}$ \\
\hline \multicolumn{4}{|l|}{ Faktor protektif eksternal } \\
\hline - Faktor keluarga (indeks) & 0,231 & 0,154 & $0,029^{\star \star}$ \\
\hline - Faktor sekolah (indeks) & 0,126 & 0,156 & $0,080^{\star}$ \\
\hline - Faktor masyarakat (indeks) & 0,015 & 0,022 & 0,767 \\
\hline - Faktor teman sebaya (indeks) & 0,155 & 0,246 & $0,005^{\star \star}$ \\
\hline Aktivitas remaja (indeks) & 0,187 & 0,144 & $0,068^{\star}$ \\
\hline$F$ & & 14,964 & \\
\hline Sig. & & $0,000^{\star \star *}$ & \\
\hline$R$ Square & & 0,624 & \\
\hline Adjusted $R$ Square & & 0,583 & \\
\hline
\end{tabular}


Remaja laki-laki cenderung memiliki faktor pelindung yang lebih sedikit dibandingkan perempuan. Orang tua yang memiliki remaja perempuan memiliki kekhawatiran yang lebih besar dibandingkan dengan orang tua yang memiliki remaja laki-laki sehingga orang tua lebih mengontrol remaja perempuan dibandingkan dengan remaja laki-laki. Remaja laki-laki lebih merasa bebas dari pengawasan orang tua dan menganggap bahwa lingkungan keluarga mengekangnya jika tidak memberi mereka kebebasan (Tung \& Dhillon, 2006). Selain faktor protektif eksternal yang berasal dari keluarga, remaja perempuan juga memiliki faktor protektif eksternal yang berasal dari teman sebaya yang lebih baik dibandingkan remaja laki-laki. Remaja perempuan merasa lebih memiliki teman yang dapat menolongnya ketika ia membutuhkan dan lebih merasa ada teman yang memujinya saat ia melakukan hal baik. Penelitian Peart, Marsh, dan Richards (2005) menyatakan bahwa orang tua dan lingkungan seperti teman sebaya yang memberikan sikap baik dan positif membuat remaja merasa berharga sehingga menumbuhkan konsep diri yang positif.

Hasil yang berbeda ditemukan pada aspek ancaman. Hasil penelitian menunjukkan bahwa remaja laki-laki lebih sering menghadapi ancaman dibandingkan dengan remaja perempuan. Hasil ini mendukung hasil penelitian Sunarti Rochimah, dan Islamia (2015) yang juga menemukan bahwa remaja laki-laki lebih banyak dihadapkan pada ancaman, diantaranya lebih sering diajak merokok, diajak tawuran, dan dipaksa terlibat tawuran dibandingkan dengan remaja perempuan.

Aktivitas remaja, baik yang dilakukan di dalam maupun di luar rumah tidak berbeda signifikan berdasarkan jenis kelamin. Secara keseluruhan, aktivitas remaja laki-laki dan perempuan tidak jauh berbeda. Hanya saja remaja laki-laki memiliki aktivitas di luar rumah yang lebih banyak dibandingkan dengan remaja perempuan. Menurut Brennan, Miller, dan Seltzer (1993), organisasi pemuda dapat memiliki pengaruh yang penting terhadap perkembangan remaja. Aktivitas yang dilakukan remaja berkisar antara 1-8 aktivitas dan jumlah aktivitas yang dilakukan remaja di luar rumah lebih banyak daripada aktivitas di rumah. Hal ini dikarenakan pada usia remaja biasanya sebagian besar waktunya dihabiskan di luar rumah bersama dengan teman sebayanya untuk melakukan berbagai aktivitas (Hurlock, 1997). Selain itu, ketersediaan akses dan fasilitas juga berpengaruh terhadap tingkat aktivitas fisik seseorang (Gordon-Larsen, Mc. Murray, \& Popkin, 2000).

Unsur pembeda kedua dalam penelitian ini adalah tipologi wilayah (remaja yang tinggal di kota dan desa). Hasil penelitian juga menunjukkan bahwa remaja yang tinggal di desa memiliki rata-rata skor protektif eksternal yang lebih besar dibandingkan dengan remaja yang tinggal di kota. Hasil tersebut menunjukkan bahwa dukungan dari lingkungan sekitar remaja di desa masih lebih baik dibandingkan dengan kota. Kehidupan kota yang semakin individualis menurunkan kepedulian masyarakat sekitar terhadap tetangganya. Masyarakat cenderung mengabaikan hal-hal yang terjadi di lingkungan sekitarnya. Kondisi tersebut menjadikan kota memiliki ancaman yang lebih banyak dibandingkan dengan desa. Hal tersebut ditunjukkan oleh hasil penelitian yang menemukan bahwa remaja yang tinggal di kota menghadapi ancaman yang lebih tinggi dibandingkan dengan remaja yang tinggal di desa. Temuan ini sejalan dengan penelitian Sunarti, Rochimah, dan Islamia (2015) yang menyatakan bahwa remaja di kota lebih banyak yang membolos dan tawuran dibandingkan dengan remaja yang tinggal di kabupaten.

Unsur pembeda ketiga dalam penelitian ini adalah status pekerjaan ibu (remaja dengan ibu yang bekerja dan tidak bekerja). Hasil penelitian menemukan bahwa resiliensi, faktor protektif internal, dan faktor protektif ekternal (sekolah dan teman sebaya) pada remaja yang memiliki ibu bekerja lebih tinggi dibandingkan remaja yang memiliki ibu tidak bekerja. Hal ini diduga jika remaja dengan ibu bekerja memiliki self-eficacy yang baik, artinya remaja yakin mengenai kemampuannya dalam melakukan tugas untuk mencapai tujuan. Hal ini sejalan dengan Almani, Abro, dan Mugheri (2012) yang menemukan bahwa ibu yang bekerja mampu membangun kepercayaan diri anak. Selain itu, remaja dengan ibu bekerja diduga dibiasakan untuk memiliki tujuan disetiap kegiatan yang dilakukan.

Penelitian ini bertujuan untuk menganalisis variabel bebas yang memengaruhi resiliensi remaja. Variabel pertama yang menentukan resiliensi remaja adalah faktor protektif internal. Faktor ini berpengaruh positif terhadap resiliensi remaja yang mengindikasikan bahwa resiliensi remaja meningkat dipengaruhi oleh bertambahnya faktor protektif internal remaja. Hal ini sejalan dengan pendapat Kalil (2003) yang mengatakan bahwa faktor protektif internal dapat menjadikan individu mampu 
bertahan dalam kondisi yang sulit atau kondisi yang tidak menguntungkan. Selanjutnya penelitian yang dilakukan oleh Ziaian et al. (2012) juga menemukan bahwa remaja yang memiliki gejala depresi atau permasalahan emosi dan perilaku memiliki daya lenting (recilience) yang rendah.

Variabel bebas kedua yang terbukti nyata menentukan resiliensi remaja adalah faktor protektif eksternal dimensi keluarga. Faktor protektif keluarga berpengaruh signifikan positif terhadap resiliensi remaja. Hasil ini mengindikasikan bahwa resiliensi pada remaja meningkat dipengaruhi oleh bertambahnya faktor protektif eksternal keluarga. Hasil penelitian ini mendukung temuan penelitian Kalil (2003) yang menemukan bahwa kebutuhan psikologis pada individu dapat terpenuhi dengan adanya dukungan yang memadai dari lingkungan berupa hubungan hangat, peraturan dan batasan, dukungan untuk mandiri, dukungan untuk berprestasi, dan role model yang positif. Hasil dalam penelitian ini juga mendukung temuan penelitian Sunarti, Rochimah, dan Islamia (2015) yang menunjukkan bahwa resiliensi remaja dapat ditingkatkan melalui peningkatkan kohesi, orientasi, berprestasi, dan orientasi terhadap moral dan religi di dalam keluarga. Dalam hubungannya dengan resiliensi, peran keluarga menjadi begitu penting. Remaja akan belajar untuk dapat bersikap mandiri, berpendirian teguh, berani mengambil keputusan, dan gigih dalam menghadapi rintangan dari internalisasi nilai-nilai, sikap, dan pengalaman yang ada di dalam keluarga.

Variabel bebas ketiga yang berpengaruh terhadap resiliensi remaja adalah faktor protektif eksternal sekolah (faktor sekolah). Faktor protektif sekolah berpengaruh signifikan positif terhadap resiliensi remaja. Hasil ini mengindikasikan bahwa peningkatan resiliensi pada remaja dipengaruhi oleh bertambahnya faktor protektif eksternal sekolah. Hasil ini mendukung temuan penelitian Sunarti, Rochimah, dan Islamia (2015) yang juga menemukan bahwa sekolah merupakan salah satu lingkungan yang paling berpengaruh terhadap resiliensi remaja. Hasil penelitian ini juga sesuai dengan pendapat Hurlington (2010) yang diacu dalam Sunarti Rochimah, dan Islamia (2015), yaitu sekolah dan guru memiliki peranan penting dalam membangun resiliensi remaja. Resiliensi dapat terbentuk melalui adanya lingkungan sekolah yang penuh dengan kepedulian dan kehangatan, adanya harapan tinggi dalam pencapaian prestasi dan perilaku yang diberikan sekolah kepada remaja, dan juga adanya kesempatan bagi remaja untuk terlibat aktif berkontribusi dalam setiap kegiatan bermakna di sekolah.

Hasil penelitian juga menemukan bahwa faktor protektif eksternal teman sebaya berpengaruh terhadap resilinesi. Hasil ini mengindikasikan bahwa resiliensi pada remaja meningkat dipengaruhi oleh bertambahnya faktor protektif eksternal teman sebaya. Lingkungan teman sebaya yang diharapkan remaja adalah adalah teman sebaya yang mampu membuat remaja merasa bahwa ada teman yang peduli terhadap mereka. Bogenschneider (1998) menyatakan bahwa peer group atau teman sebaya dapat menjadi faktor pelindung juga dapat menjadi ancaman bagi remaja. Teman dapat menjadi ancaman apabila remaja berhubungan dengan teman-teman yang terlibat dalam masalah perilaku. Teman sebaya dapat menjadi kelompok yang memberikan pengaruh negatif terhadap remaja terutama pada remaja yang kurang mendapat pengarahan dari orang tua. Seperti yang ditemukan oleh Karina, Hastuti, dan Alfiasari (2013) bahwa terdapat hubungan positif signifikan antara keterikatan peer group dengan perilaku bullying. Artinya semakin terikat remaja dengan peer group maka kecenderungan melakukan bullying semakin tinggi.

Penelitian ini menemukan bahwa aktivitas remaja yang berpengaruh signifikan positif terhadap resiliensi remaja. Hasil ini mengindikasikan bahwa peningkatan resiliensi pada remaja dipengaruhi secara nyata oleh peningkatan aktivitas remaja baik di dalam maupun di luar rumah. Aktivitas di lingkungan lebih berperan dalam mengurangi perilaku bermasalah secara umum pada remaja dibandingkan dengan perannya dalam mendorong kompetensi akademis yang merupakan salah satu indikator resiliensi akademis. Keterlibatan remaja dalam beragam aktivitas kegiatan di dalam maupun di luar rumah merupakan salah satu bentuk pengalihan kelebihan energi yang dimiliki remaja sehingga remaja tidak menyia-nyiakan energi yang dimilikinya untuk hal yang tidak berguna dan yang dapat menimbulkan bahaya bagi dirinya.

Keterlibatan remaja dalam beragam aktivitas juga dapat meningkatkan kemampuan dalam bersosialisasi, dukungan, dan hubungan dengan masyarakat. Sejalan dengan hasil penelitian LaFromboise et al. (2006) yang mengatakan bahwa remaja yang memiliki dukungan masyarakat yang tinggi adalah remaja yang memiliki kemampuan dalam 
mencegah, mengantisipasi, beradaptasi, dan menghadapi masalah (resiliensi). Hal ini dapat terjadi karena kegiatan yang dilakukan oleh remaja bersama dengan orang dewasa akan mendorong mereka untuk dapat mengembangkan bakat dan ketrampilannya. Brennan (2007) mengemukakan bahwa partisipasi remaja dalam masyarakat merupakan salah satu faktor pelindung yang penting dan mampu meningkatkan penguasaan kompetensi sosial, pemecahan masalah, otonomi, dan rasa terhadap suatu tujuan yang dimiliki keluarga. Alimi (2005) menambahkan bahwa keikutsertaan remaja dalam aktivitas kelompok awalnya bisa saja merupakan salah satu cara mereka untuk dapat bertahan dari pengaruh buruk lingkungan, hanya saja setelah terlibat secara intensif dalam aktivitas kelompok mereka merasakan kepuasan.

\section{SIMPULAN DAN SARAN}

Penelitian ini menemukan bahwa ancaman pada remaja laki-laki dan remaja yang tinggal di kota lebih tinggi dibandingkan dengan ancaman pada remaja yang tinggal di desa dan remaja perempuan. Sebaliknya, faktor protektif (internal dan eksternal) dan resiliensi pada remaja perempuan lebih tinggi dibandingkan dengan remaja laki-laki. Faktor protektif eksternal, aktivitas di luar rumah, dan resiliensi pada remaja di desa lebih tinggi dibandingkan dengan remaja di kota. Faktor protektif, faktor protektif internal, faktor protektif eksternal (sekolah dan teman sebaya), dan resiliensi remaja dengan ibu bekerja lebih tinggi dibandingkan remaja dengan ibu tidak bekerja.

Selain itu, penelitian ini menemukan bahwa resiliensi remaja dipengaruhi oleh faktor protektif (internal dan eksternal) dan aktivitas remaja. Resiliensi remaja akan meningkat oleh bertambahnya faktor protektif (internal dan eksternal) dan aktivitas remaja. Berdasarkan hasil tersebut, penelitian ini menyarankan beberapa hal kepada peneliti, orang tua, sekolah, dan masyarakat dalam rangka meningkatkan resiliensi remaja. Pada penelitian selanjutnya, diharapkan dapat melaksanakan penelitian pada individu yang berisiko tinggi seperti pada anak jalanan atau anak korban bencana. Selanjutnya, saran untuk orang tua adalah diharapkan dapat memperhatikan, membimbing, dan mendukung remaja agar faktor-faktor internal dalam dirinya dapat berkembang dengan baik dan dapat menjadikan remaja memiliki kemampuan dalam mencegah, mengantisipasi, beradaptasi, dan menghadapi kesulitan dan tantangan di masa yang akan datang.
Sekolah diharapkan dapat menyelenggarakan kegiatan-kegiatan yang positif untuk mendukung terbentuknya remaja yang tangguh, tidak mudah menyerah, dan kuat dalam menghadapi kesulitan. Masyarakat diharapkan dapat meningkatkan kepedulian terhadap anakanak di lingkungan dan membangun kebersamaan melindungi anak-anak dari berbagai ancaman di lingkungan, melaksanakan program pembangunan resiliensi, dan mencegah masuknya hal-hal yang dapat meningkatkan keterpaparan anak terhadap situasi yang membahayakan.

\section{DAFTAR PUSTAKA}

Alimi, R. M. (2005). Resiliensi remaja high risk ditinjau dari faktor protektif (studi di Kelurahan Tanah Tinggi, Kecamatan Johar Baru, Jakarta Pusat) (Tesis). Universitas Indonesia, Jakarta, Indonesia.

Almani, A. S., Abro, A., \& Mugheri, R. A. (2012). Study of the effects of working mothers on the development of children in Pakistan. International Journal of Humanities and Social Science, 2(11), 164-171.

Alriksson-Schmidt, A. I., Wallander, J., \& Biasini F. (2007). Quality of life and resilience in adolescents with a mobility disability. Journal of Pediatric Psychology, 32(3), 370-379.

Benzies K. \& Mychasiuk R. (2008). Fostering family resiliency: a review of the key protective factors. Child and Family Social Work, 14, 103-114. doi: 10.1111/j.1365-2206.2008.00586.

Bogenschneider, K. (1998). What youth need to succeed: The roots of resiliency. Wisconsin Family Impact Seminar Briefing Report. Wisconsin, US: Center for Excellencee in Family Studies. Diunduh dari https://www.purdue.edu/hhs/hdfs/fii/wpcontent/uploads/2015/07/s_wifis10c01.pd f.

Brennan, M. A. (2007). Conceptualizing resiliency: an interactional perspective for community and youth development. Child Care in Practice, 14(1), 55-64.

Brennan, J. G., Miller, L. E., \& Seltzer, J. (1993). Influence tactics and effectiveness. The Journal of Social Psychology, 133, 747-748.

Fergus, S., \& Zimmerman, M. A. (2005). Adolescent resilience: a framework for 
understanding healthy development in the face of risk. Annu. Rev. Public Health, 26, 399-419.

Furlong, M. J., Ritchey, K. M., \& O’Brennan, L. M. (2009). Developing norms for the California resilience youth development module: internal assets and school resources subscales. The California School Psychologist, 14, 35-46.

Gordon-Larsen, P., Mc.Murray, R.G., \& Popkin, B. M. (2000). Determinants of adolescent physical activity and inactivity patterns. Journal of The American Academy of Pediatrics, 105(6), 1-8. doi: 10.1542/peds.105.6.e83.

Hurlock, E. B. (1997). Perkembangan Anak. Meitasari Tjandra, penerjemah. Jakarta, ID: Erlangga.

Kalil, A. (2003). Family resilience and good child outcomes: a review of a literature. New Zealand, NZ: Center for Social Research and Evalution, Ministry of Social Development.

Kaplan, H. B. (1999). Toward an understanding of resilience: A critical review of definitions and models in resilience and development: positive life adaptations. New York, NY: Kluwer Academic/Plenum Publishers.

Karina, Hastuti, D., \& Alfiasari. (2013). Perilaku bullying dan karakter remaja serta kaitannya dengan karakteristik keluarga dan peer group. Jurnal IImu Keluarga dan Konsumen, 6(1), 20-29.

LaFromboise, T. D., Hoyt, D. R., Oliver, L., \& Whitbeck, L. B. (2006). Family, community, and school influences on resilience among American Indian Adolescent in the Upper Midwest. Journal of Community Psychology, 34(2), 193209.

Laras, E. (2015). Hubungan antara khauf dengan perilaku agresif siswa MA NU Demak (Skripsi). Universitas Islam negeri Walisongo, Semarang, Indonesia.

Mandleco B. L. \& Peery J. C. (2000). An organizational framework for conceptializing resilience in children. Journal of Child and Adolescent Psychiatric Nursing, 13(3), 99-111.

Masten, A. S. (2001). Ordinary magic: Resilience processes in development. Journal of American Psychologist, 56(3), 227-238.
Masten, A. S., \& Coatsworth, J. D. (1998). The development of competence in favorable and unfavorable environments. Lessons from research on successful children. $A m$ Psychol, 53(2), 205-220.

Martiastuti, K. (2011). Resiliensi remaja berdasarkan jenis kelamin, jenis sekolah dan tipologi wilayah (Tesis). Sekolah Pascasarjana Institut Pertanian Bogor, Bogor, Indonesia.

Moos, B. S., \& Moos, R. H. (2009). Family environment scale. California, US: Mind Garden. Diambil dari www.mindgarden.com/products/fescs.htm [diunduh 10 Juli 2015].

Peart, N. D., Marsh, H. W., \& Richards, G. E. (2005). The physical self description questionnaire: futhering research linking physical self-concept, physical activity and phsical education. Paper Presented at the AARE Annual Conference, Parramatta.

Resnick M. D., Bearman P. S., Blum R. W., Bauman K. E., Harris K.M., Jones J., Tabor J., Beuhring T., Sieving R., Shew M., Ireland M., Bearinger L. H., \& Udry R. (1997). Protecting adolescents from harm: findings from the national longitudinal study on adolescent health. Journal of the American Medical Association, 278, 823-832.

Ruhidawati, C. (1995). Pengaruh pola pengasuhan, kelompok teman sebaya dan aktivitas remaja terhadap kemandirian (Tesis). Sekolah Pascasarjana Institut Pertanian Bogor, Bogor, Indonesia.

Sunarti, E., Rochimah, N., \& Islamia, I. (2015). Kajian faktor resiliensi anak. Laporan Penelitian Kementerian Pemberdayaan Perempuan dan Perlindungan Anak Republik Indonesia.

Santrock, J. W. (2011). Life-span development. Edisi ke-13. New York, US: MCGrew-Hill.

Steinberg, L. (1993). Adolescence. Edisi ke-3. New York, US: McGraw-Hill, Inc.

Tung, S. \& Dhillon, R. (2006). Emotional autonomy in relation to family environment: a gender perspective. Journal of the Indian Academy of Applied Psychology, 32(3), 201-212.

Ungar, M. (2008). Resilience across culture. British Journal of Social Work, 38(2), 218235. doi: $10.1093 / \mathrm{bjsw} / \mathrm{bcl} / 343$. 
Volia, M. S. (2007). Gambaran resilience pada remaja korban bencana alam di rumah anak madani (Tesis). Fakultas Psikologi Universitas Sumatera Utara, Sumatera Utara, Indonesia.

Wagnild, G., \& Young, H. (1993). Development and psychometric evaluation of the resilience scale. Journal of Nursing Measurement, 1(2), 165-178.

Yuliatin. (2007). Resilience pelecehan seksual yang terjadi pada masa anak-anak (childhood sexual abuse) (Tesis). Universitas Muhammadiyah Malang, Malang, Indonesia.
Ziaian, T., de Anstiss, H., Antonioun, G., Baghurst, P., \& Sawyer, M. (2012). Resilience and its association with depression, emotional and behavioural problems, and mental health service utilisation among refugee adolescents living in South Australia. International Jpurnal of Population Research, 1-9. doi:10.1155/2012/485956.

Zolkoski, S. M., \& Bullock, L. M. (2012). Resilience in children and youth: a riview. Children and Youth Service Review, 34, 2295-2303. 